\title{
Parodontologie in de Praktijk
}




\section{Parodontologie in de Praktijk}

J.P. van Hoeve

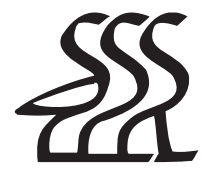

Bohn Stafleu van Loghum Houten 2008 
(C) 2008 Bohn Stafleu van Loghum, onderdeel van Springer Uitgeverij Alle rechten voorbehouden. Niets uit deze uitgave mag worden verveelvoudigd, opgeslagen in een geautomatiseerd gegevensbestand, of openbaar gemaakt, in enige vorm of op enige wijze, hetzij elektronisch, mechanisch, door fotokopieën of opnamen, hetzij op enige andere manier, zonder voorafgaande schriftelijke toestemming van de uitgever.

Voor zover het maken van kopieën uit deze uitgave is toegestaan op grond van artikel 16b Auteurswet $1912 \mathrm{j}^{\circ}$ het Besluit van 20 juni 1974, Stb. 351, zoals gewijzigd bij het Besluit van 23 augustus 1985, Stb. 471 en artikel 17 Auteurswet 1912, dient men de daarvoor wettelijk verschuldigde vergoedingen te voldoen aan de Stichting Reprorecht (Postbus 3051, 2130 KB Hoofddorp). Voor het overnemen van (een) gedeelte(n) uit deze uitgave in bloemlezingen, readers en andere compilatiewerken (artikel 16 Auteurswet 1912) dient men zich tot de uitgever te wenden.

Samensteller(s) en uitgever zijn zich volledig bewust van hun taak een betrouwbare uitgave te verzorgen. Niettemin kunnen zij geen aansprakelijkheid aanvaarden voor drukfouten en andere onjuistheden die eventueel in deze uitgave voorkomen.

ISBN 9789031351756

NUR 887

Ontwerp omslag en binnenwerk: TEFF, Hurwenen

Opmaak binnenwerk: Damocles Media, Amsterdam/Wim van de Kerkhof

Deze uitgave kwam tot stand met medewerking van de B.V.Diensten Nederlandse Vereniging voor Parodontologie

Bohn Stafleu van Loghum

Het Spoor 2

Postbus 246

3990 GA Houten

www.bsl.nl 


\section{Ten geleide}

\section{Visie en lange adem}

Wie veel paropatiënten behandelt en deze over een lange periode vervolgt, weet hoe moeilijk het is om consistente gegevens over vele, lange jaren te verzamelen. Je begint vol enthousiasme aan het documenteren van een interessante casus, maar om die documentatie door de jaren heen vol te houden is moeilijker: de camera ligt niet klaar, je hebt geen tijd, het komt de volgende keer wel, de patiënt is verhuisd, etc., etc.

Het is de verdienste van Jan van Hoeve dat hij het belang inzag van protocollair werken, lang voordat er een 'officieel paroprotocol NVvP' was. Bovendien zag hij in hoe waardevol het kon zijn om behalve de noodzakelijke klinische registraties en röntgenfoto's ook veel klinische foto's te maken. Omdat hij behalve als parodontoloog tevens als algemeen practicus werkzaam was, nam hij veelal ook het restauratieve deel van de behandeling voor zijn rekening en kon aldus laten zien dat op een gezond fundament uitstekend gebouwd kan worden.

Al deze inspanningen hebben geleid tot juweeltjes van behandelingen en documentatie waarover Jan in een periode van tien jaar regelmatig heeft gepubliceerd in het vaktijdschrift TandartsPraktijk.

Toen Jan van Hoeve twee jaar geleden aankondigde te zullen stoppen met zijn serie bijdragen, ontstond bij de Nederlandse Vereniging voor Parodontologie het idee om deze artikelen te verzamelen in een boek, zodat het materiaal toegankelijk zou blijven voor eenieder die bij parodontale behandelingen betrokken is: tandarts, mondhygiënist, preventieassistent en parodontoloog. Om zo'n uitgave aantrekkelijk en leesbaar te maken volstond het echter niet om alleen maar de losse artikelen te bundelen. Jan van Hoeve heeft het materiaal uit zijn artikelen gegroepeerd, waar mogelijk geactualiseerd en op elkaar afgestemd, en aldus een uitstekend leesbaar en geheel op de praktijk gericht boek samengesteld.

Uit de literatuur weten we dat parodontale behandelingen, mits goed uitgevoerd en mits goed gecontroleerd, uitstekende en blijvende resultaten opleveren: gebitsbehoud in een ontstekingsvrije conditie. Het is niettemin minstens zo leerzaam om aan de hand van casuïstiek daadwerkelijk te zien dat het werkt en hoe het werkt! En niet alleen leerzaam, maar ook motiverend om zelf weer met enthousiasme en met plezier te werken aan een gezond fundament.

Dr.Jan Jansen

Voorzitter Nederlandse Vereniging voor Parodontologie

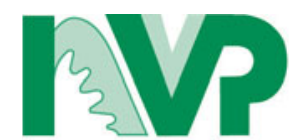




\section{Voorwoord}

\section{Beste Lezer,}

Als tandarts geef je meestal langdurige zorg. Zo was het tenminste toen ik in 1970 mijn praktijk begon.

Al snel werd me duidelijk dat succesvolle tandheelkunde alleen mogelijk is als deze gebaseerd is op preventie en dat restauratieve tandheelkunde alleen dan kan slagen als het parodontium gezond is. Zo ontstond mijn belangstelling voor de parodontologie.

Om het resultaat van mijn handelen op langere termijn te kunnen beoordelen, heb ik vanaf het begin zo veel mogelijk gevallen klinisch, röntgenologisch en fotografisch gedocumenteerd.

De casuïstiek en de evaluaties die zodoende ontstonden zijn door mij beschreven in meer dan vijftig bijdragen, die in het tijdschrift TandartsPraktijk zijn gepubliceerd. In dit boek is een ruime selectie van deze bijdragen bijeengebracht.

De bundeling bestaat uit vier onderdelen. In het eerste deel komen min of meer algemene onderwerpen aan bod, deel twee bevat artikelen over behandelingsplanning en behandeling, deel drie bestaat uit casuïstiek, en ter afsluiting de bijdragen over regeneratie en de relatie tussen parodontologie en restauratieve tandheelkunde.

Ik hoop dat mijn ervaringen en mijn daarop gebaseerde visie u zullen helpen uw patiënten zo goed mogelijk te behandelen - en met hetzelfde plezier als waarmee ik dat altijd gedaan heb.

Jan van Hoeve

Met dank aan Wim van de Kerkhof voor de opmaak van de bundeling. 


\section{Inhoudsopgave}

Ten geleide

Voorwoord

De in dit boek gebruikte pocket/parodontiumstatus

\section{Algemeen. Onderzoek. Diagnose.}

1. Aandacht voor het parodontium

Hoe zijn tegenvallende resultaten van parodontale behandelingen te vermijden? 15

Het gevaar van parodontitis

Het belang van vroege diagnostiek

Tips bij het herkennen van endo-paroproblemen

Pigmentatie van het tandvlees $\quad 35$

$\begin{array}{ll}\text { Lokale recessie van de gingiva bij onderincisieven } & 41\end{array}$

Beschadiging van de gingiva door de tandenborstel 45

9. De geschiedenis van recessies en een vrij gingivatransplantaat 47

Behandelingsplanning. Behandeling.

10. Het dilemma 'behoud of extractie' 49

11. Tandsteen verwijderen 55

12. Niet-chirurgische parodontale behandeling 59

13. Een gemutileerd gebit met parodontale afbraak 63

$\begin{array}{ll}\text { 14. Een doeltreffende sanering } & 67\end{array}$

15. Parodontale nazorg móet 71

16. Necrotiserende ulceratieve gingivitis/parodontitis 85

$\begin{array}{ll}\text { 17. Lokale juveniele parodontitis } & 91\end{array}$

18. Hoe ver kun je gaan met een parodontale behandeling? 101

\section{Casuïstiek}

19. Initiële behandeling van een complex probleem 113

20. Spontane standscorrectie 117

21. Een verkeerde inschatting? Aa-positief! 121

22. Een plaqueprobleem 125

23. 25 jaar paropatiënt met ups en downs 129

24. Een moeilijke patiënt. Een hopeloos geval? 135

\section{Botregeneratie. Relatie parodontologie - restauratieve tandheelkunde}

$\begin{array}{lll}\text { 25. } & \text { Herstel van angulaire botdefecten na conventionele therapie } & 141 \\ \text { 26. } & \text { Geleide weefselregeneratie in de praktijk } & 143 \\ \text { 27. } & \text { Molaren en doorgankelijke furcaties } & 149 \\ \text { 28. } & \text { Kronen en het parodontium } & 153 \\ \text { 29. } & \text { De partiële frameprothese en het parodontium } & 157 \\ \text { 30. } & \text { Eenvoudige esthetische correcties van lange en scheve tanden } & 163 \\ \text { 31. } & \text { Een on(be)handelbaar onderfront } & 167 \\ \text { 32. } & \text { Dubieuze molaren gebruiken als brugpijler } & 171\end{array}$




\section{De in dit boek gebruikte pocket/parodontiumstatus}

Om bij het lezen van casuïstiek een snel inzicht te krijgen in de parodontale toestand, gebruiken we een aangepaste pocket/parodontiumstatus waarop de meest relevante gegevens in een oogopslag te zien zijn.

De pocketdieptes worden op basis van meting rondom het element opgenomen en de diepste meting per vlak wordt weergegeven. Dieptes tot $4 \mathrm{~mm}$ worden in witte vlakken genoteerd, 4 en $5 \mathrm{~mm}$ in gele, en dieper dan 5 $\mathrm{mm}$ in rode.

Recessies worden buccaal of linguaal aangegeven door een cijfer met een minteken ervoor $(-5)$.

De furcatieproblemen worden aangegeven in rondjes bij de molaren. In de bovenkaak voor respectievelijk mesiaal, buccaal en distaal, in de onderkaak buccaal, op de volgende wijze:

o $($ open rondje $)=$ geen toegankelijkheid van de furcatie

$\varnothing$ (open rondje met een streep erdoor $)=$ toegankelijk tot een derde

- $($ zwart rondje $)=$ voor meer dan de helft toegankelijk

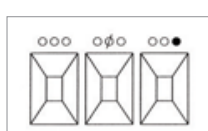

$\begin{array}{lll}26 & 27 & 28\end{array}$

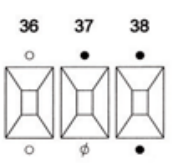

Bij ondermolaren betekent beiderzijds zwart: buccolinguaal doorgankelijk.

Bij bovenmolaren mesiaal en distaal zwart: mesiodistaal doorgankelijk.

De mobiliteit is in drie graden genoteerd in romeinse cijfers (I, II, III).

Bloeding, plaque, pus en gegevens als hypertrofie en het ontbreken van aangehechte gingiva en verdere relevante bevindingen zijn niet aangegeven, omdat deze gegevens in de tekst en in de bijschriften bij de klinische beelden en de röntgenfoto's vermeld worden.

Onderstaand een voorbeeld van zo'n status, waarop o.a. valt af te lezen:

$\sim$ de 16 met aan de buccale zijde als diepste meting $7 \mathrm{~mm}$ en een toegankelijke furcatie van meer dan $1 / 2$ buccaal

$\sim$ de 23 met mesiaal een pocket van 4, buccaal 8 , distaal 10 en palatinaal $8 \mathrm{~mm}$, buccaal een recessie van $5 \mathrm{~mm}$ en een mobiliteitsgraad 1

$\sim$ de 45 met de diepste meting aan het distale vlak $9 \mathrm{~mm}$, bucaal 2, mesiaal 7 en linguaal 7 , linguaal een recessie van $2 \mathrm{~mm}$ en mobiliteitsgraad 2

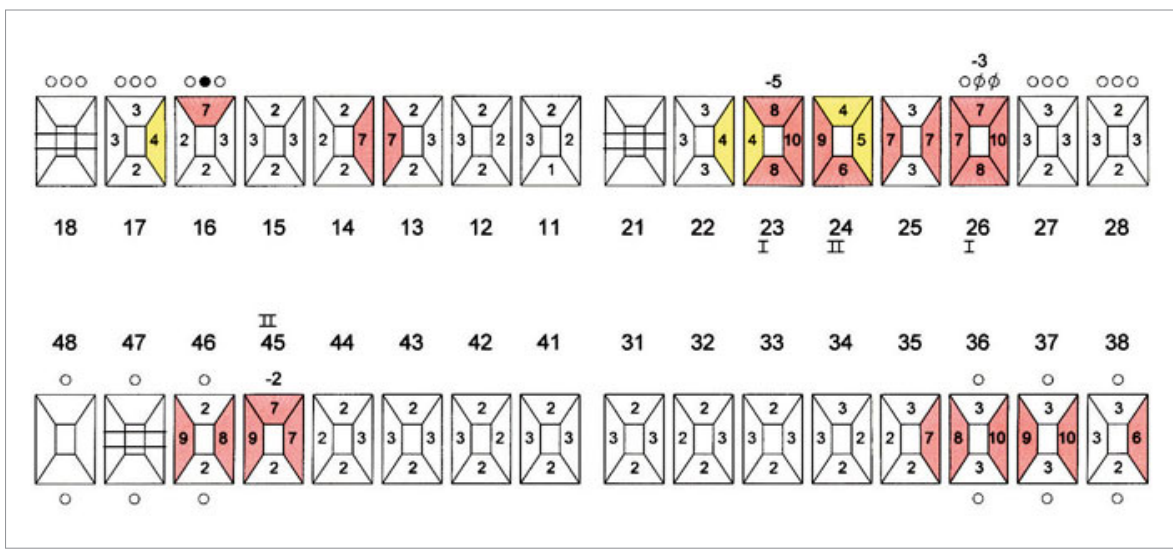

